\title{
PENGARUH PAYMENT POINT ONLINE BANK (PPOB) TERHADAP PERCEPATAN ALIRAN KAS ( STUDI KASUS DI PT. PLN (PERSERO) PROVINSI ACEH)
}

\author{
Indrayani \\ 1,2Prodi Akuntansi Fakultas Ekonomi dan Bisnis Universitas Malikussaleh Lhokseumawe \\ indrayani@unimal.ac.id
}

\begin{abstract}
This study aims to identify the influence of Payment Point Online Bank (PPOB) on the cash flow acceleration at PT. Perusahaan Listrik Negara (Persero). This study uses secondary data in the form of financial statements during 2017-2018 taken from the central office of PT. Perusahaan Listrik Negara (Persero) of Aceh Province. The samples used are 38 offices of PT. Perusahaan Listrik Negara (Persero) in Aceh Province. The method used to analyze the data is simple linear regression analysis. The results of this study indicate that the Payment Point Online Bank $(X)$ influences significantly on the cash flow acceleration $(Y)$ at PT. PLN of Aceh Province during 2017-2018.
\end{abstract}

Keywords: Payment Point Online Bank (PPOB), Cash Flow Acceleration.

\section{PENDAHULUAN}

Seiring dengan meningkatnya kebutuhan akan tenaga listrik di suatu daerah dan sejalan dengan meningkatnya kegiatan ekonomi dan kesejahteraan masyarakat di daerah tersebut maka meningkat pula jumlah pelanggan PT Perusahaan Listrik Negara, menandakan bahwa semakin meningkat pula receipt/kas masuk yang diterima PT Perusahaan Listrik Negara baik dari penggunaan jasa listrik maupun non listrik. Pengelolaan kas masuk dalam Organisasi intern PT Perusahaan Listrik Negara itu sendiri, saat ini selain dilakukan oleh bidang keuangan, Sumber Daya Manusia dan Administrasi, juga dilakukan sebagian tugas fungsi keuangan yaitu penerimaan uang dari pelanggan dan untuk pengendalian piutang usaha dilaksanakan oleh Bidang Niaga dan Pelayanan Pelanggan.

Perusahaan Listrik Negara merupakan suatu perusahaan yang bergerak dalam bidang penyediaan energi listrik di Indonesia. Pada awalnya PT. PLN ditetapkan sebagai pemegang kuasa usaha ketenagalistrikan. Namun sejak tahun 1992, pemerintah memberikan kesempatan pada sektor swasta untuk bergerak dalam bisnis penyediaan tenaga listrik. Oleh karena itu, Bulan Juni 1994 PLN dialihkan dari perusahaan umum menjadi perusahaan perseroan (persero), sehingga nama perusahaan ini menjadi PT. PLN (Persero).

PT Perusahaan Listrik Negara (Persero) merupakan suatu perusahaan yang bergerak dalam bidang pelayanan jasa energi listrik di Indonesia. Adanya perkembangan teknologi komputer dan jaringan telekomunikasi, maka dibuatlah berbagai macam aplikasi yang dapat membantu perusahaan dalam melaksanakan kegiatan bisnisnya. Salah satu aplikasi tersebut adalah Payment Point Online
Bank (PPOB). Fenomena yang terjadi sebelum tahun (2010) PT Perusahaan Listrik Negara (Persero) menerapkan sistem pembayaran konvensional yang banyak melibatkan petugas Payment Point (PP) untuk membantu mengumpulkan dana dari pelanggan seperti Koperasi Unit Desa serta Bank, berdasarkan kontrak Nomor. 057.PJ/041/WIL-LPG/2007 tentang penerimaan pembayaran tagihan listrik secara online, maka PT Perusahaan Listrik Negara (Persero) bekerja sama dengan PT POS Indonesia (Persero) dalam menerima pelunasan rekening listrik oleh pelanggan melalui System Online Payment Point (SOPP). Namun, uang pembayaran rekening listrik tersebut yang diterima petugas Payment Point tidak langsung disetor ke rekening Bank receipt PT Perusahaan Listrik Negara (Persero), tetapi melalui proses penyetoran fisik uang dan memerlukan waktu yang lama. Kekurangan atau permasalahan dalam penerapan sistem PPOB. Berdasarkan survey karyawan PLN Rayon Kota Lhokseumawe, Yusiati, tanggal survey (13 Maret 2019), seperti yang diungkapkan salah satu pejabat PLN yaitu terletak pada masalah teknis yang kerap terjadi pada sistem PPOB, Dimana pada waktu pembayaran mengalami trouble atau offline jaringan seluler. Sehingga proses transaksi mengalami kegagalan maka loket tidak dapat melakukan transaksi. Terlepas dari pro dan kontra yang terjadi dengan adanya PPOB, selama semua dapat dikomunikasikan dan tidak ada informasi yang ditutupi sebagaian pelanggan listrik akan menerima. Namun disisi lain dalam kegiatan operasional serta memberikan pelayanannya kepada pelanggan PT PLN (Persero) mengalami hambatan. Dalam usahanya untuk meningkatkan kinerja, salah satu hambatan yang dihadapi adalah 
adanya saldo piutang atau yang sering disebut dengan tunggakan rekening listrik. Adanya keterlambatan pembayaran rekening listrik menyebabkan PT Perusahaan Listrik Negara (Persero) merugi karena tunggakan rekening listrik. Hal ini disebabkan karena masyarakat sering

\section{LANDASAN TEORI}

\section{Teori keagenan (Agency Theory)}

Bagi perusahaan yang berbentuk

Perseroan Terbatas (PT) terlebih untuk perusahaan, seringkali terjadi pemisahan antara pengelola perusahaan dengan pemilik perusahaan. Disamping itu, untuk perusahaan yang berbentuk perseroan terbatas, tanggug jawab pemilik hanya terbatas pada modal yang disetorkan. Artinya, apabila perusahaan mengalami kebangkrutan, maka modal sendiri (ekuitas) yang telah disetorkan oleh para pemilik perusahaan mungkin sekali akan hilang, tetapi kekayaan pribadi pemilik tidak akan diikutsertakan untuk menutup kerugian tersebut (Husnan dan Pudjiastuti; 2006).

\section{Pengertian Payment Point Online Bank (PPOB)}

Salah satu sistem dimana mekanisme pembayaran tagihan yang sangat lebih aman, mudah dan murah seerta proses yang tidak rumit. Payment Point Online Bank atau disingkat (PPOB) ini merupakan layanan pembayaran tagihan secara Online real time 24 jam sehingga proses rekonsiliasi baik data dan dana bisa lebih cepat dan akurat serta aman.

Menurut Rani (2008) dalam Anggrita (2014) Payment Point Online Bank (PPOB) adalah sistem pembayaran rekening secara tunai melalui teknologi tinggi dengan menggunakan perangkat lunak yang didesain secara khusus dengan memberikan kemudahan kepada masyarakat. membayar melebihi batas waktu yang telah ditetapkan. Masyarakat kurang memahami akan kewajibannya sebagai pelanggan listrik yaitu membayar rekening tepat pada waktunya. Sehingga percepatan aliran kas tidak bekerja secara optimal menurut karyawan PLN. (Dhiyah,2010).

Sistem Payment Point Online Bank (PPOB) sendiri merupakan pengembangan dari Semi Online Payment Point (SOPP), dimana transaksi berlangsung secara semi online, dan memiliki jeda waktu sehingga update data dan arus keuangan memerlukan waktu. Sedangkan pada sistem Payment Point Online Bank (PPOB), semua berlangsung secara online, dimana transaksi manual hanya terjadi pada pelanggan dan loket Payment Point Online Bank (PPOB), sehingga update data dan arus keuangan berlangsung real time.

\section{Konseptual sistem PPOB (Payment Point Online Bank).}

PPOB (Payment Point Online Bank) adalah satu kesatuan sistem hardware dan sistem software aplikasi, jaringan komunikasi data dan rekonsiliasi data sehingga dapat berfungsi sebagai media interaksi sistem pembayaran tagihan apapun secara online dengan pihak bank sebagai penyelenggara sekaligus penampung dana pelanggan untuk diteruskan kepada mitra kerjanya

\section{System Online Payment Point (SOPP)}

Payment Point konvensional aadalah salah satu mekanisme mode pembayaran tagihan dengan cara konvensional dimana cara proses pelimpahan dana pembayaran ke rekening received PT Perusahaan Listrik Negara (Persero) dilakukan dengan cara melakukan penyetoran dana melalui Bank secara tunai (Arisandi, 2013)..

\section{Kerangka Konseptual}

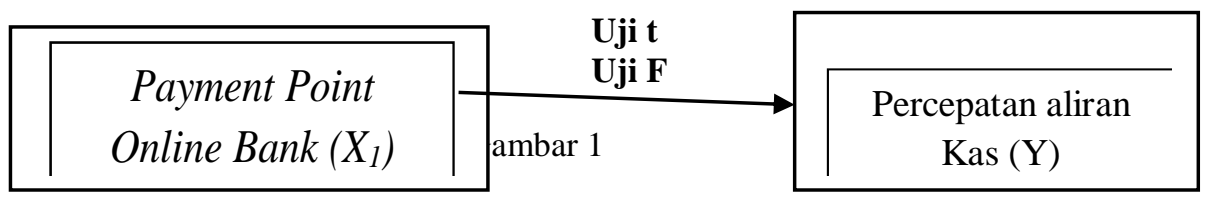

\section{Hipotesis}

Ha :Payment Point Online Bank berpengaruh terhadap Aliran Kas Pada PT Perusahaan Listrik Negara (Persero) Aceh

Ho :Payment Point Online Bank tidak berpengaruh terhadap Percepatan Aliran
Kas Pada PT Perusahaan Listrik Negara (Persero) Aceh

\section{METODE PENELITIAN}

\section{Populasi dan Sampel \\ Menurut}

Umar(2006:121),populasimengacupadakeseluruhan 
kelompokorang,kejadian

atauhalminatyanginginpenelitiinvestigasi.

Populasidalampenelitianiniadalah karyawan yang menggunakan sisteminformasiakuntansi

Universitas Malikussaleh.

Pemilihan sampel yang digunakan dalam penelitian iniadalah teknik Sampling Jenuh. Sampling jenuh adalah teknik penentuan sampel apabila semua anggota populasi digunakan sebagai sampel (Sugiono,2012:96). Istilah lain sampel jenuh adalah sensus, dimana semua anggota populasi dijadikan sampel. Hal ini sering dilakukan apabila jumlah populasi relatif kecil, kurang 30 atau penelitian yang membuat generalisasi dengan kesalahan yang sangat kecil.

\section{Jenis dan sumber data}

Jenis data yang digunakan dalam penelitian ini adalah adalah data subyek yaitu data yang berupa opini, sikap, atau pengalaman seseorang yang menjadi subjek penelitian (Indriantoro dan Supomo, 2013). Data subjek merupakan dokumentasi yang diperoleh melalui laporan keuangan. Sedangkan sumber data yang digunakan dalam penelitian ini adalah Data skunder yaitu data diperoleh dari setiap laporan keuangan PT. PLN.

\section{Teknik Pengumpulan Data}

Teknik pengumpulan data yang digunakan dalam penelitian ini adalah Telaah Dokumen. Telaah dokumen dilakukan dengan penelusuran terhadap beberapa dokumen yang berkaitan dengan variabel penelitian guna mendapatkan data sekunder yang akan digunakan dalam analisis permasalahan (Anwar Sanusi 2011), yaitu menyangkut Kas Masuk dari Payment Point Online Bank (PPOB)

\section{Operasional Variabel}

Tabel 1

\begin{tabular}{|l|c|l|l|c|}
\hline No & Variabel & \multicolumn{1}{|c|}{ Definisi } & \multicolumn{1}{c|}{ Rumus } & Skala \\
\hline 1 & $\begin{array}{c}\text { Percepatan } \\
\text { aliran kas } \\
(\mathrm{Y})\end{array}$ & $\begin{array}{l}\text { Kas merupakan uang } \\
\text { tunai yang dimiliki } \\
\text { perusahaan dan dapat } \\
\text { segera digunakan setiap } \\
\text { saat.(kasmir, 2010:40) }\end{array}$ & $\begin{array}{l}\text { Y=Ln(Jumlah kas pada } \\
\text { periode yang akan diamati) } \\
\text { (kasmir, 2010:40) }\end{array}$ & Rasio \\
\hline 2 & Payment & $\begin{array}{l}\text { Sistem pembayaran } \\
\text { Point Online } \\
\text { rekening secara tunai } \\
\text { Bank (PPOB) } \\
\text { melalui teknologi dan } \\
\text { perangkat lunak untuk } \\
\text { memberikan }\end{array}$ & $\begin{array}{l}\text { Penjualan Payment Point } \\
\text { Online Bank Per Tahun }\end{array}$ & Rata-Rata Piutang Pelangan \\
Murniatiet.al (2013:37) & \\
& $\begin{array}{l}\text { kemudahan kepada } \\
\text { masyarakat. } \\
\text { (Anggrita,dkk, 2014) }\end{array}$ & & \\
& & & & \\
& & & & \\
\end{tabular}

\section{Uji Regresi Linier sederhana}

Adapun persamaan regresi berganda menurut Supranto (2001), adalah hubungan memperkirakan/meramalkan antara satu variabel terikat dengan beberapa variabel bebas dengan formulasinya. Persamaan umum regresi linier sederhana adalah :

$$
\mathrm{Y}=\alpha+\beta_{1} \mathrm{X}_{1}+\varepsilon
$$

Keterangan :

$$
\begin{aligned}
& Y=\text { Percepatan Aliran Kas } \\
& \alpha=\text { Konstanta, yaitu besarnya }
\end{aligned}
$$

nilai $Y$ ketika nilai $X=0$ $\beta=$ Arah koefsien regresi, yang menyatakan perubahan nilai Y apabila terjadi perubahan nilai $X$. Bila (+) maka arah garis akan naik, dan bila (-) maka nilai garis akan turun

$\mathrm{X}=$ Variabel bebas / variabel yang memepengaruhi Percepatan Aliran Kas

$\varepsilon=$ faktor-faktor lain yang mempengaruhi variabel $\mathrm{Y}$ 


\section{Hasil Dan Pembahasan}

Uji Kualitas Data

4.1.2.1 Payment Point Online Bank (PPOB)

Tabel 4.1

PPOB PT PLN Provinsi Aceh Tahun 2017 dan 2018

\begin{tabular}{|c|c|c|c|}
\hline NO & Jenis Transaksi & PPOB 2017 & PPOB 2018 \\
\hline 1 & Merduati & 0,5865 & 0,6321 \\
\hline 2 & Lambaro & 0,5787 & 0,4617 \\
\hline 3 & Keudebieng & 0,6192 & 0,3413 \\
\hline 4 & Jantho & 0,6019 & 0,1530 \\
\hline 5 & Sabang & 0,5394 & 0,7944 \\
\hline 6 & Syiah Kuala & 0,6250 & 1,0412 \\
\hline 7 & Sigli Kota & 0,5773 & 1,4319 \\
\hline 8 & Beureunun & 0,6350 & 0,7551 \\
\hline 9 & Meureudu & 0,5972 & 0,6247 \\
\hline 10 & Lhokseumawe Kota & 0,6173 & 0,6127 \\
\hline 11 & Kreung Geukuh & 0,6362 & 1,3314 \\
\hline 12 & Geudong & 0,5944 & 1,0684 \\
\hline 13 & Lhoksukon & 0,5764 & 1,2045 \\
\hline 14 & Panton Labu & 0,5399 & 0,6522 \\
\hline 15 & Bireuen & 0,6365 & 0,6823 \\
\hline 16 & Matang & 0,6641 & 0,4898 \\
\hline 17 & Samalanga & 0,5351 & 0,6796 \\
\hline 18 & Gandapura & 0,5411 & 0,5822 \\
\hline 19 & Takengon & 0,5758 & 0,5408 \\
\hline 20 & Janarata & 0,5808 & 0,5053 \\
\hline 21 & Langsa Kota & 0,5390 & 0,5753 \\
\hline 22 & Kuala Simpang & 0,6066 & 0,5417 \\
\hline 23 & Idi & 0,5944 & 0,5767 \\
\hline 24 & Peureulak & 0,5651 & 0,5487 \\
\hline 25 & Kuta Cane & 0,6073 & 0,5932 \\
\hline 26 & Blang Kejeren & 0,6240 & 0,4721 \\
\hline 27 & Meulaboh Kota & 0,5796 & 0,6848 \\
\hline 28 & Calang & 0,5913 & 0,5368 \\
\hline 29 & Jeuram & 0,6568 & 0,6715 \\
\hline 30 & Sinabang & 0,6901 & 0,5066 \\
\hline 31 & Teunom & 0,6401 & 0,4872 \\
\hline 32 & Subulussalam Kota & 0,7203 & 0,6774 \\
\hline 33 & Rimo & 0,7716 & 0,6149 \\
\hline 34 & Singkil & 0,6494 & 0,5488 \\
\hline 35 & Kota Fajar & 0,6949 & 0,6732 \\
\hline 36 & Tapak Tuan & 0,6444 & 0,5283 \\
\hline
\end{tabular}




\begin{tabular}{|l|l|l|r|}
\cline { 2 - 3 } 37 & Labuhan Haji & 0,7012 & 0,6465 \\
\hline 38 & Blang Pidie & 0,7015 & 0,6761 \\
\hline
\end{tabular}

Sumber: Data diolah tahun 2019

Pada tabel 4.1 dapat dilihat PPOB dari PT.PLN Provinsi Aceh selama periode 2017 dan 2018, dapat dilihat pada tahun 2017 PT.PLN Cabang Samalanga memperoleh PPOB terendah dengan Nilai 0,5351 hal ini Jumlah penjualan PPOB yang rendah dan tingginya piutang yang terjadi pada tahun tersebut. Pada tahun yang sama PT.PLN Cabang Rimo memperoleh PPOB tertinggi dengan Nilai 0,7716 hal ini dikarenakan banyaknya Penjualan PPOB dan jumlah piutang yang rendah. pada tahun 2017 PT.PLN Cabang Jantho memperoleh PPOB terendah dengan Nilai 0,1530 hal ini Jumlah penjualan PPOB yang rendah dan tingginya piutang yang terjadi pada tahun tersebut. Pada tahun yang sama PT.PLN Cabang Sigli memperoleh PPOB tertinggi dengan Nilai 1,4319 hal ini dikarenakan banyaknya Penjualan PPOB dan jumlah piutang yang rendah.

\section{Uji Asumsi Klasik \\ a. Uji Normalitas}

\section{Normal P-P Plot of Regression Standardized \\ Residual}

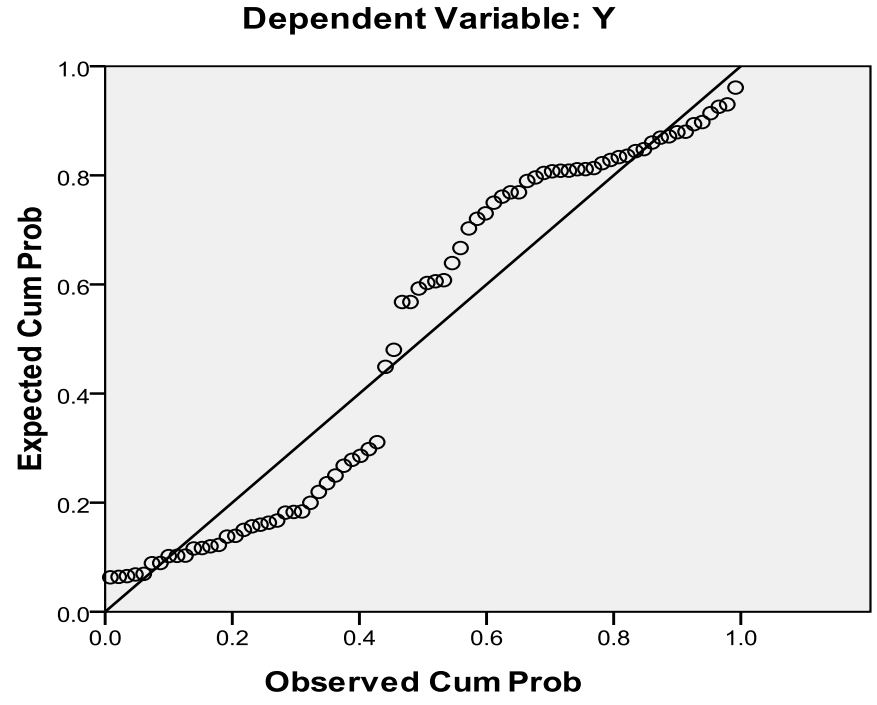

Gambar 1

Berdasarkan Gambar 1 diatas, grafik normal probability plot menunjukkan bahwa model regresi layak dipakai dalam penelitian ini karena grafik normal plot terlihat titik-titik menyebar disekitar garis diagonal serta penyebaran mengikuti arah garis diagonal menunjukkan pola distribusi normal, sehingga model regresi memenuhi asumsi normalitas.

\section{b. Uji Multikolinieritas}

Tabel 5

\begin{tabular}{|l|l|l|l|}
\hline \multirow{2}{*}{ Variabel } & \multicolumn{2}{|l|}{ Collinearity Statistic } & Keterangan \\
\cline { 2 - 3 } & Tolerance & VIF & \\
\hline $\mathrm{X}$ & 1.000 & 1.000 & Tidak ada multikolinearitas \\
& & & \\
\hline
\end{tabular}

Sumber: Data Primer, diolah (2019)

Dari Tabel 4.2 di atas terlihat bahwa nilai tolerance dan nilai VIF menunjukkan tidak ada satu variabel yang memiliki nilai VIF lebih dari 10 dan nilai tolerance juga menunjukkan tidak satu variabel bebas yang memiliki nilai. tolerance kurang dari $10 \%$. Dan ini berarti tidak ada korelasi 
antar variabel bebas yang nilainya lebih dari $90 \%$. Hasil itu menandakan bahwa model regresi yang

\section{c. Uji Heterokedastisitas}

dihasilkan tidak terjadi multikolinieritas

Scatterplot

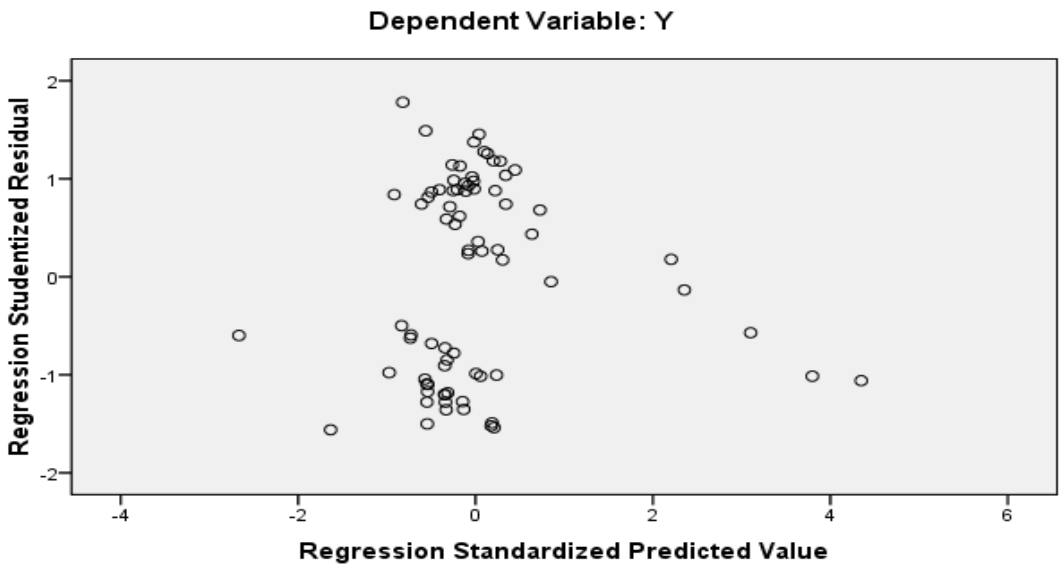

Gambar 2

Dari Gambar 4.2 di atas terlihat bahwa titik yang terdapat pada grafik scatterplot menyebar secara acak serta tersebar baik di atas maupun di bawah angka 0 pada sumbu Y. Hal ini dapat disimpulkan bahwa tidak terjadi heteroskedastisitas pada model regresi, sehingga model regresi layak

\section{Uji Regresi Linier Berganda}

dipakai untuk memprediksi variabel dependen berdasarkan masukkan variabel independen.

Tabel 6

\begin{tabular}{|ll|r|r|r|r|r|}
\hline & & \multicolumn{2}{|c|}{$\begin{array}{c}\text { Unstandardized } \\
\text { Coefficients }\end{array}$} & \multicolumn{2}{c|}{$\begin{array}{c}\text { Standardized } \\
\text { Coefficients }\end{array}$} & \\
\cline { 3 - 5 } Model & \multicolumn{1}{|c|}{$\mathrm{B}$} & Std. Error & \multicolumn{1}{c|}{ Beta } & \multicolumn{1}{c|}{$\mathrm{t}$} & \multicolumn{1}{c|}{ Sig. } \\
\hline 1 & (Constant) & .133 & .001 & & 115.066 & .000 \\
& $\mathrm{X}$ & .008 & .002 & .476 & 4.657 & .000 \\
\hline
\end{tabular}

Sumber: Data Primer, (diolah) 2019

Berdasarkan Tabel 4.4 di atas dapat dilihat koefisien dari masing-masing variabel dan konstanta yang menjadi observasi dalam penelitian ini adalah koefisien (X) 0.008 dan konstanta 0.133 Hal ini berarti variabel independen berpengaruh terhadap Percepatan Aliran Kas. Secara persamaan dapat ditulis sebagai berikut:

$$
\mathrm{Y}=0.133+0.008 \mathrm{X}+\mathrm{e}
$$

Dari persamaan tersebut dapat dijelaskan bahwa pengaruh PPOB Terhadap Percepatan

\section{Pengujian Hipotesis}

Hasil Pengujian Hipotesis Secara Parsial ( Uji t )
Aliran Kas. Dari hasil analisis menunjukkan bahwa:

a. Konstanta $(\alpha)$ sebesar 0.133, hal ini menyatakan bahwa jika tidak ada pengaruh (peningkatan/penurunan) nilai variabel $\mathrm{X}$, maka tingkat Percepatan Aliran Kas 13.3\%

b. Koefisien PPOB (X) sebesar 0.008, hal ini menyatakan bahwa jika terjadi peningkatan PPOB sebesar 1, maka akan meningkatkan Percepatan Aliran Kas sebesar 0.8\% 


\begin{tabular}{|c|c|c|c|c|c|c|}
\hline \multirow{2}{*}{\multicolumn{2}{|c|}{ Model }} & \multicolumn{2}{|c|}{$\begin{array}{l}\text { Unstandardized } \\
\text { Coefficients }\end{array}$} & \multirow{2}{*}{$\begin{array}{c}\text { Standardized } \\
\text { Coefficients } \\
\text { Beta }\end{array}$} & \multirow[b]{2}{*}{$\mathrm{T}$} & \multirow[b]{2}{*}{ Sig. } \\
\hline & & B & Std. Error & & & \\
\hline \multirow[t]{2}{*}{1} & (Constant) & .133 & .001 & & 115.066 & .000 \\
\hline & $\mathrm{X}$ & .008 & .002 & .476 & 4.657 & .000 \\
\hline
\end{tabular}

Sumber : Hasil Penelitian, diolah (2019)

Berdasarkan Tabel 4.9 diatas dapat dilihat bahwa nilai thitung untuk PPOB (X) sebesar 4,657.Untuk mengetahui tingkat signifikansi secara parsial pada tingkat kepercayaan $100 \%$ pengujian hipotesis dengan uji $t$ dilakukan dengan membandingkan antara thitung dengan $t$-tabel. Sebagai berikut:

a. Pembuktian pengujian hipotesis variabel Payment Point Online Bank (X)
Secara parsial (uji t) yang diperoleh dari nilai $\mathrm{T}_{\text {hitung }}$ pada persamaan regresi linear Sederhana menyatakan bahwa Payment Point Online Bank berpengaruh signifikan (nyata) terhadap percepatan aliran kas, dikarenakan

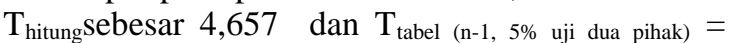
1,665 di mana Thitung>Ttabel dengan nilai signifikansi 0,000 dibawah 0,05.Sehingga hipotesis pertama $\left(\mathrm{H}_{1}\right)$ diterima.

\section{Hasil Pengujian Hipotesis Simultan (Uji F)}

Tabel 8

ANOVA ${ }^{b}$

\begin{tabular}{|ll|r|r|r|r|r|}
\hline Model & & Sum of Squares & df & Mean Square & F & Sig. \\
\hline 1 & Regression & .000 & 1 & .000 & 21.690 & $.000^{\mathrm{a}}$ \\
& Residual & .001 & 74 & .000 & & \\
& Total & .001 & 75 & & & \\
\hline
\end{tabular}

a. Predictors: (Constant), $\mathrm{X}$

b. Dependent Variable: Y

Sumber: Hasil Penelitian, diolah (2019)

Berdasarkan Tabel 4.6 di atas dapat dilihat bahwa nilai $F_{\text {hitung }}$ sebesar 21.690. sedangkan $F_{\text {tabel }}$ pada

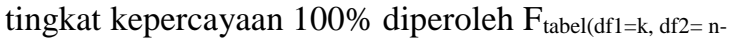
$\mathrm{k}-1,5 \%)=3,97$, atau dengan kata lain $F_{\text {hitung }}>$ $\mathrm{F}_{\text {tabel. }}$ Dan juga dapat dilihat dari sig $0,000<0,05$. Pengujian hipotesis dengan uji $\mathrm{F}$ dilakukan dengan membandingkan antara $F_{\text {hitung }}$ dengan $F_{\text {tabel }}$, dan nilai signifikansinya.Dengan demikian berarti secara simultan variabel PPOB (X) berpengaruh secara signifikan terhadap Percepatan Aliran Kas (Y) pada PT.PLN Provinsi Aceh Periode 20172018.Sehingga hipotesis $\left(\mathrm{H}_{1}\right)$ diterima.

\section{PEMBAHASAN}

Pengaruh PPOB terhadap Percepatan Aliran Kas

Berdasarkan hasil penelitian menunjukkan bahwa PPOB berpengaruh secara signifikan terhadap percepatan aliran kas hal ini dikarenakan Sistem Pembayaran Tagihan Rekening Listrik yang diterapkan PT PLN (Persero) Provinsi Aceh secara konvensional belum dapat mengendalikan kas masuk dengan cepat dan aman. Penerimaan kas mulai dari pembayaran oleh pelanggan sampai ke rekening receipt PT PLN (Persero) Kantor Pusat bahwa ada penyetoran fisik uang dari payment point ke rekening receipt Rayon.

Kurun waktu yang diperlukan dalam mengendalikan kas masuk mulai dari pelanggan hingga ke rekening receipt PT PLN (Persero) Kantor Pusat kurang lebih 3 hari. Hal ini dikarenakan adanya penyetoran penerimaan kas secara berjenjang mulai dari rekening receipt Rayon ke rekening Area ke rekening distribusi dan ke rekening PT PLN (Persero) Kantor Pusat. Pada sistem Online uang pelunasan tagihan rekening listrik lebih cepat masuk ke rekening receipt PLN Pusat. Berdasarkan Edaran Direksi PT PLN (Persero) No. : 010.E/012/DIR/2002 tentang Mekanisme Arus Dana Receipt, uang dari pelanggan akan masuk ke rekening receipt PLN Distribusi dan dilanjutkan secara otomatis ke rekening receipt PLN Pusat..

Terdapat dua jenis layanan Payment Point On line Bank, yaitu Downline Bank dan Delivery Channel Bank. Pada Downline Bank pelanggan non nasabah bank dapat terlayani karena pembayaran melalui 
collecting agent atau downliner seperti KUD, Toko/Supermarket, Yayasan maupun perorangan, dengan kata lain setiap orang mempunyai kesempatan untuk menjadi downliner. Pada Delivery Channel terbatas hanya untuk nasabah bank dengan memanfaatkan fasilitas bank seperti ATM, E-banking, SMS banking, Teller, Phone Banking, dll. Sistem Downline Bank dan Delivery Channel.

\section{KESIMPULAN DAN SARAN}

\section{Kesimpulan}

Hasil penelitian ini menunjukkan bahwa variabel Payment Point Online Bank (X), berpengaruh secara signifikan terhadap percepatan aliran kas (Y) pada PT.PLN Provinsi Aceh Periode 2017-2018 berdasarkan nilai $F_{\text {hitung }}$ sebesar 21.690. sedangkan $\mathrm{F}_{\text {tabel }}$ pada tingkat kepercayaan $100 \%$

\section{DAFTAR PUSTAKA}

Atik, dan Ratminto. 2005. Manajemen Pelayanan, di sertai dengan pengembangan model konseptual, penerapan citizen's charter dan standar pelayanan minimal. Yogyakarta: Pustaka Pelajar

Arisandi, 2013. Penerapan Penerapan Penerapan Penerapan System Online Payment Point (Sopp) Dalam Pembayaran Rekening Listrik Di Pt.Pos (Persero) Cabang Kota Samarinda. Yogyakarta: BPFE.

Arikunto, Suharsimi. 2006. Prosedur Penelitian Suatu Pendekatan Praktek. Jakarta: PT. Rineka Cipta

Baridwan, Zaki. 2010. Sistem Akuntansi Penyusunan Prosedur dan Metode. Edisi 5. Yogyakarta : BPPE

Bodnar, George H. dan William S. Hopwood. 2007. Sistem Informasi Akuntansi (Edisi 9). Jakarta: Salemba

Boediono, 2014. Ekonomi Internasional Pengantar Ilmu Ekonomi No. 3. Penerbit : BPFE UGM

Dewi (2009). Manajemen Keuangan Perusahaan. Jakarta: Ghalia Indonesia

Dhiyah Budhiningrum.(2010). Implementasi Strategi penurunan tunggakan rekening listrik di PT PLN (Persero) APJ Surakarta. Skripsi S1. Program studi Ilmu Administrasi, Fakultas Ilmu Sosial dan Politik, Universitas Surakarta. diperoleh $\mathrm{F}_{\text {tabel }(\mathrm{df} 1=\mathrm{k} \text {, df2= n-k-1, 5\%) }}=3,97$, atau dengan kata lain $\mathrm{F}_{\text {hitung }}>\mathrm{F}_{\text {tabel. }}$. Dan juga dapat dilihat dari sig $0,000<0,05$.

Saran

Berdasarkan hasil penelitian, maka Saran dari hasil penelitian ini adalah:

1. Tetap konsisten menerapkan sistem pembayaran tagihan rekening listrik dengan Payment Point Online Bank (PPOB). Melalui Payment Point Online Bank (PPOB) kas masuk sampai ke rekening receipt PT PLN (Persero) Kantor Pusat, Payment Point Online Bank (PPOB) dapat meningkatkan pelunasan tagihan rekening listrik karena dapat menjangkau daerah terpelosok.

meningkatkan sistem pengawasan dalam pengimlementasian PPOB agar dapat memaksimalkan Aliran kas.

Denziana Angrita, Fiscal Yusuf, dkk. (2014). Pengaruh Payment Point Online Bank (PPOB) dalam Percepatan Aliran Kas pada PT PLN ( Persero) Distribusi Lampung. Jurnal Akuntansi dan Keuangan. Volume 5. Hlm.50-2001

Edaran Direksi PT PLN (Persero) No: 010.E/012/DIR/2002 tentang Mekanisme Arus Dana Receipt. Jakarta

Eddy herjanto .2003. Manajemen produksi dan operasi. cetakan ketiga Jakarta PT Grasindo

Ghozali, Imam 2011. Aplikasi Analisis Multivariate Dengan Program SPSS. Semarang: BP Universitas Diponegoro

Giri, 2012, Modified Chitosan Hydrogels as Drug Delivery and Tissue Engineering Systems: Present Status and Applications, Acta Pharm. Sin. B, 1-11Husein, M Fahri, Wibowo A.,(2002).

Sistem Informasi Manajemen. AMP

JKPM.Yogyakarta

Husnan, dan Pudjiastuti.(2006). Dasar-Dasar Manajemen Keuaangan. Edisi Ketujuh. Yogyakarta: UPP AMP YKPN.

Ikatan Akuntan Indonesia. 2012. Standar Akuntansi Keuangan. Jakarta: IAI

Ikatan Akuntan Indonesia (IAI). 2007. Standar Akuntansi Keuangan-1 September 2007. Jakarta:Salemba Empat

Iskandar. 2008. Metodologi Penelitian Pendidikan dan Sosial (Kuantitatif dan Kualitatif). Jakarta: GP Press. 
Indriantoro, 2002, Metodologi Penelitian Bisnis untuk Akuntansi dan Manajemen, Edisi Pertama, BPFE, Yogyakarta.

Jensen, Meckling .(1976). kutipanArifin, Zainal. 2005 (hlm 60-66) dalam Skripsi Riza SetyaPrabawa 2006. "Analisis Pengaruh Biaya Keagenan, Kesempatan, Investasi dan Posisi Likuiditas perusahaan terhadap Kebijakan Deviden". Universitas Islam Indonesia

Kasmir. 2015. Analisis Laporan Keuangan. Jakarta : PT Raja Grafindo Persada.

Kotler, Philip dan Kevin Lane Keller. 2007. Manajemen pemasaran jilid 2. Jakarta: Indeks.

Keputusan Direksi PLN No. 021.K/0599/DIR/1995 tgl 23 Mei 1995 tentang Pedoman dan Petunjuk Tata Usaha Pelanggan.

Keputusan Direksi PLN No. 082.K/010/DIR/2002 tanggal 25 Juni 2002 tentang sistem aplikasi tentang pengelolaan piutang pelanggan.

Masdupi, (2005)."Analisis Dampak struktur kepemilikan pada Kebijakan Hutang dalam Mengontrol Konflik Keagenan." Jurnal Ekonomi Bisnis vol.20, No.1. Desember .56-69

Mulyadi. (2004). Akuntansi. Bandung: Pustaka Pelajar

Mulyadi. 2001. Sistem Akuntansi Edisi Tiga. Jakarta : Salemba Empat.

Munawir, S. 2001. Analisa Laporan keuangan. Yogyakarta : Liberty

Moh'd et.al. (1998). The Impact of Ownership Structure on Corporate Debt Policy: a Time-Series Cross-Sectional Analysis: Financial Review 33. Pge 85-98

O'Brien, James A. 2003. Introduction to Information Systems : Essentials forthe EBusiness Enterprise. (11th ed). New York: Irwin/McGraw-Hill.

Ratminto dan Atik Septi Winarsih. 2010 Manajemen Pelayanan (Pengembangan model konseptual, penerapan citizens charter dan standar pelayanan). Jakarta: Pustaka Pelajar.
Rianto A, (2011), Metode penelitian kualitaif, kualitatif dan kuantitatif. Yogyakarta.

Sanusi, Anwarr. 2011. Metodologi penelitian bisnis. Salemba Empat. Jakarta.

Situmorang, (2008). Analisis Data Penelitian. Cetakan Kedua. Medan: USU Press.

Skousen, smith .2001. Akuntansi keuangan menengah. Edisi kesembilan ,jilid satu, terjemahan.salemba empat,Jakarta

Sugiono, 2009. Metode Penelitian Bisnis. Bandung : CV Alfabeta

Sutrisno. 2001. Akuntansi Keuangan Teori, Konsep, dan Aplikasi. Yogyakarta : EKONISIA.

Supranto, 2001. Pengukuran Tingkat Kepuasan Pelanggan untuk Menaikkan Pangsa Pasar, Penerbit Rineka Cipta, Jakarta, 230,243

Smith, Jay M and K. Fred Skousen. 2005. Akuntansi Intermediate, Edisi 9, Erlangga, Jakarta

Skousen, K. Fred dan Jay M. Smith. 2001. Akuntansi Keuangan Menengah. Edisi ketiga belas, buku satu. Jakarta:Erlangga

Sugiyono. 2007. Metode Penelitian Administrasi. Bandung: CV.Alfabeta

Triyono, 2007. Sistem online payment poin. Jakarta: Pustaka Pelajar.

UU No.10 Tahun 1998 No 7 Tahun 1998 tentang perbankan (pasal 1 butir 2).

UU Republik Indonesia No. 30 tahun 2009 tentang Ketenaga listrikan Pasal 27 dan Pasal 29.

Wibowo dan Abubakar (2002:133). Akuntansi

Keuangan Dasar 2. Jakarta : PT. Grasindo.

Williams dan Sawyer. 2003. Using Information Technology: A Practical Introduction to Computers and Communications. London: Career Education Noermayanti, 2015. herman dkk. efektifitas penerapan sistem payment point online bank (PPOB) pada PT PLN area medium. Jurnal administrasi public volume.1.

Yusuf maulana, kurniawan median dkk. (2012). Pengaruh Pembayaran Listrik online (PPOB) terhadap Pengendalian Internal 
Kas pada PT PLN (Persero) Distribusi Jabar dan Banten. Jurnal Ekonomi, Bisnis \& Entrepreneurship Vol. 6, No. 1, April 2012, 51-63 ISSN 2443-0633

Rahayu tanti.2015. Pengaruh Penerapan Payment Point Online Bank (PPOB) terhadap fee based income PT Bank Muamalat Indonesia Tbk. Jurnal keuangan perbankan syariah 2015 http://www.pln.co.id

https://new.internetstart.net/search\#gsc.q=teori $\% 20$ agency $\% 20$ menurut $\% 20$ perusahaan \&gsc.s ort= diunduh tanggal 25 maret 2019

https://repository.widyatama.ac.id/xmlui/bitstream/ handle/123456789/4522/Bab\%202.pdf?sequence $=1$

$\underline{0}$ diunduh tanggal 26 maret 2019 